\title{
Association Study of Serotonin 3 Receptor Subunit Gene Variants in Antipsychotic-Induced Weight Gain
}

\author{
Clement C. Zai ${ }^{a-c}$ Arun K. Tiwaria, ${ }^{a}$ Nabilah I. Chowdhury ${ }^{a}$ Eva J. Brandl ${ }^{a, b, d}$
} Sajid A. Shaikh ${ }^{a}$ Natalie Freeman ${ }^{a}$ Jeffrey A. Lieberman ${ }^{e}$ Herbert Y. Meltzer ${ }^{f}$ James L. Kennedy ${ }^{a, b}$ Daniel J. Müller ${ }^{a, b}$

${ }^{a}$ Neurogenetics Section, Campbell Family Mental Health Research Institute, Centre for Addiction and Mental Health, ${ }^{b}$ Department of Psychiatry, and ' Laboratory Medicine and Pathobiology, University of Toronto, Toronto, ON, Canada; ${ }^{d}$ Department of Psychiatry and Psychotherapy, Charité Universitätsmedizin Berlin, Berlin, Germany; e Department of Psychiatry, College of Physicians and Surgeons, Columbia University, New York State Psychiatric Institute, Lieber Center for Schizophrenia Research, New York Presbyterian Hospital and Columbia University Medical Center, New York, NY, and f Department of Psychiatry and Beh Sci, Feinberg School of Medicine, Northwestern University, Chicago, IL, USA

\section{Keywords}

Serotonin 3A and 3B receptor genes (HTR3A, HTR3B) ·

Schizophrenia - Antipsychotic-induced weight gain •

Pharmacogenetics

\begin{abstract}
Background: Schizophrenia (SCZ) is a chronic severe neuropsychiatric disorder, where pharmacological treatment has been hindered by adverse effects, including antipsychoticinduced weight gain (AIWG) and related complications. Genetic studies have been exploring the appetite regulation and energy homeostasis pathways in AIWG with some promising leads. The serotonin system has been shown to participate in these pathways. Methods: In the current study, we examined single nucleotide polymorphisms across the serotonin receptor genes HTR3A and HTR3B. Prospective weight change was assessed for a total of 149 SCZ patients of European ancestry. Results: We did not find the
\end{abstract}

\section{KARGER}

() 2017 S. Karger AG, Basel tested HTR3A or HTR3B gene markers to be associated with AIWG in our sample. Conclusion: Our preliminary findings suggest that these receptors may not play a major role in predicting AIWG.

() 2017 S. Karger AG, Basel

\section{Introduction}

Treatment of schizophrenia (SCZ) symptoms with second-generation antipsychotics, such as clozapine and olanzapine, is often accompanied by significant weight gain experienced in up to $30 \%$ of treated patients. While the underlying mechanisms of antipsychotic response and side effects remain uncertain, genetic factors appear to play a prominent role [1-6].

J.L.K. and D.J.M. are co-senior authors.
Dr. Daniel J. Müller or Dr. James L. Kennedy

Neurogenetics Section, Campbell Family Mental Health Research Institute Centre for Addiction and Mental Health, R31 250 College Street, Toronto, ON M5T 1R8 (Canada)

E-Mail daniel.mueller@ camh.ca or jim.kennedy@ camh.ca 
Table 1. Demographic information for the study sample of European ancestry $(n=149)$

\begin{tabular}{llllr}
\hline Samples & GER $(n=86)$ & US1 $(n=52)$ & US2 $(n=11)$ & $p$ value \\
\hline Age, years $^{\mathrm{a}}$ & $35.49 \pm 12.19$ & $33.73 \pm 7.51$ & $41.25 \pm 5.37$ & 0.055 \\
Males:females $^{\mathrm{c}}$ & $50: 36$ & $32: 20$ & $11: 0$ & 0.015 \\
Clozapine or olanzapine/others $^{\mathrm{c}}$ & $26 / 60$ & $52 / 0$ & $8 / 3$ & $<0.001$ \\
Study duration, weeks $^{\mathrm{a}}$ & $5.12 \pm 1.55$ & $6.00 \pm 0.00$ & $10.55 \pm 4.18$ & $<0.001$ \\
Weight change, kg $^{\mathrm{b}}$ & $3.27 \pm 3.95$ & $2.83 \pm 4.03$ & $3.88 \pm 4.15$ & 0.681 \\
Percentage weight change $^{\mathrm{b}}$ & $3.96 \pm 4.79$ & $4.09 \pm 5.78$ & $5.58 \pm 6.64$ & 0.636 \\
\hline
\end{tabular}

Values represent mean \pm SD unless otherwise indicated. ${ }^{a} p$ value from Kruskal-Wallis tests. ${ }^{\mathrm{b}} p$ value from analysis of variance. ${ }^{c} p$ values from Fisher's exact tests.

There is evidence that the serotonin system has a role in the regulation of food intake [7]. The serotonin-2C receptor has been previously genetically associated with antipsychotic-induced weight gain (AIWG) [8]; however, the role of the serotonin-3 receptor (5-HT3) has not been explored. Ondansetron, a 5-HT3 antagonist that is used to treat chemotherapy-induced emesis [9], has been shown to block the suppression of food intake by serotonin [7] or methamphetamine administration [10]. Another 5-HT3 antagonist, tropisetron, blocks glucose-induced weight gain in mice [11]. More specifically, the 5-HT3 receptor may mediate the insulin secretion from pancreatic beta cells in response to glucose during pregnancy [12]. Mice deficient in 5-HT3 receptor also appeared to lessen the high-fat diet induced weight gain [13].

The serotonin 3 receptor is a pentameric ligand-gated cation-selective ion channel that, through its presynaptic and postsynaptic localization, regulates the release of neurotransmitters [14]. It has been shown to be antagonized by clozapine [15], an antipsychotic with high propensity for significant weight gain. The 15.4-kb HTR3A gene (HGNC:5297), which is mapped to chromosomal region 11q23.2, codes for the 5-HT3 receptor, alpha subunit, while the adjacent $47.6-\mathrm{kb}$ HTR3B gene (HGNC:5296), mapped to 11q23.1, codes for the beta subunit. In the present study, we aim to investigate the possible association between the HTR $3 A$ and HTR3B genes and AIWG.

\section{Methods}

\section{Clinical Diagnostic Criteria}

We included 149 participants of self-reported European ancestry from three independent clinical studies (clinical and demographic information included in Table 1). Diagnosis of SCZ was based on the Structured Diagnostic Interviews for DSM-IIIR and/ or DSM-IV diagnoses (SCID, American Psychiatric Association, 1994 [16]) for Samples US1 and US2, or an interview for both DSM and ICD diagnoses as in Sample GER. Two trained and experienced investigators reviewed the interview scoring, medical records, and clinical summary to reach a best-estimate consensus diagnosis [17]. In case of incongruities, another psychiatrist performed reviews to provide the final decision on the diagnosis. Adult probands with DSM-IIIR/IV diagnosis of SCZ or schizoaffective disorder were included. Exclusion criteria include a history of drug dependence (substance and severe alcohol use disorders), drug-induced psychosis, major neurological disorder including epilepsy, or cranial injury with significant loss of consciousness. The study has been approved by our local Research Ethics Board, and each participant gave written informed consent for participating in the study after they were given the complete study description. All 149 subjects were self-reported as of European ancestry, and 86 of them received clozapine or olanzapine during the study period.

\section{Samples}

Sample GER $(n=86)$ was collected at the Charité University Medicine, Berlin, Germany (DJ Müller). Patients, 18-60 years old, diagnosed with SCZ or schizoaffective disorder according to DSM-IV and ICD-10 criteria, were included (more details have been described elsewhere [18]). Briefly, these patients were started on antipsychotic medications and followed for up to 6 weeks for weight change in a naturalistic study. The antipsychotics included haloperidol, olanzapine, risperidone, aripiprazole, quetiapine, and amisulpride. Patients from Sample US1 $(n=52)$ were recruited from Case Western Reserve University in Cleveland, $\mathrm{OH}$, USA (H.Y.M.) or Hillside Hospital in Glen Oaks, NY, USA (J.A.L.) [19]. These SCZ patients under DSM-III-R diagnosis were treatment-refractory or intolerant to typical antipsychotic therapy [20]. After a 2- to 4-week wash-out period without medication (unless clinically necessary), clozapine was administered, and weight change from baseline was assessed after 6 weeks. Clozapine serum levels were monitored during the course of the treatment to ascertain compliance. Sample US2 $(n=11)$ [21] consists of inpatients who had not responded adequately to previous treatment [22]. Patients with a history of non-response to clozapine, olanzapine, or risperidone, and those who were not tolerant to clozapine, haloperidol, olanzapine, or risperidone were excluded. The US2 participants came from four psychiatric state hospitals ( 2 in New York and 2 in North Carolina) and were as- 
HTR3B

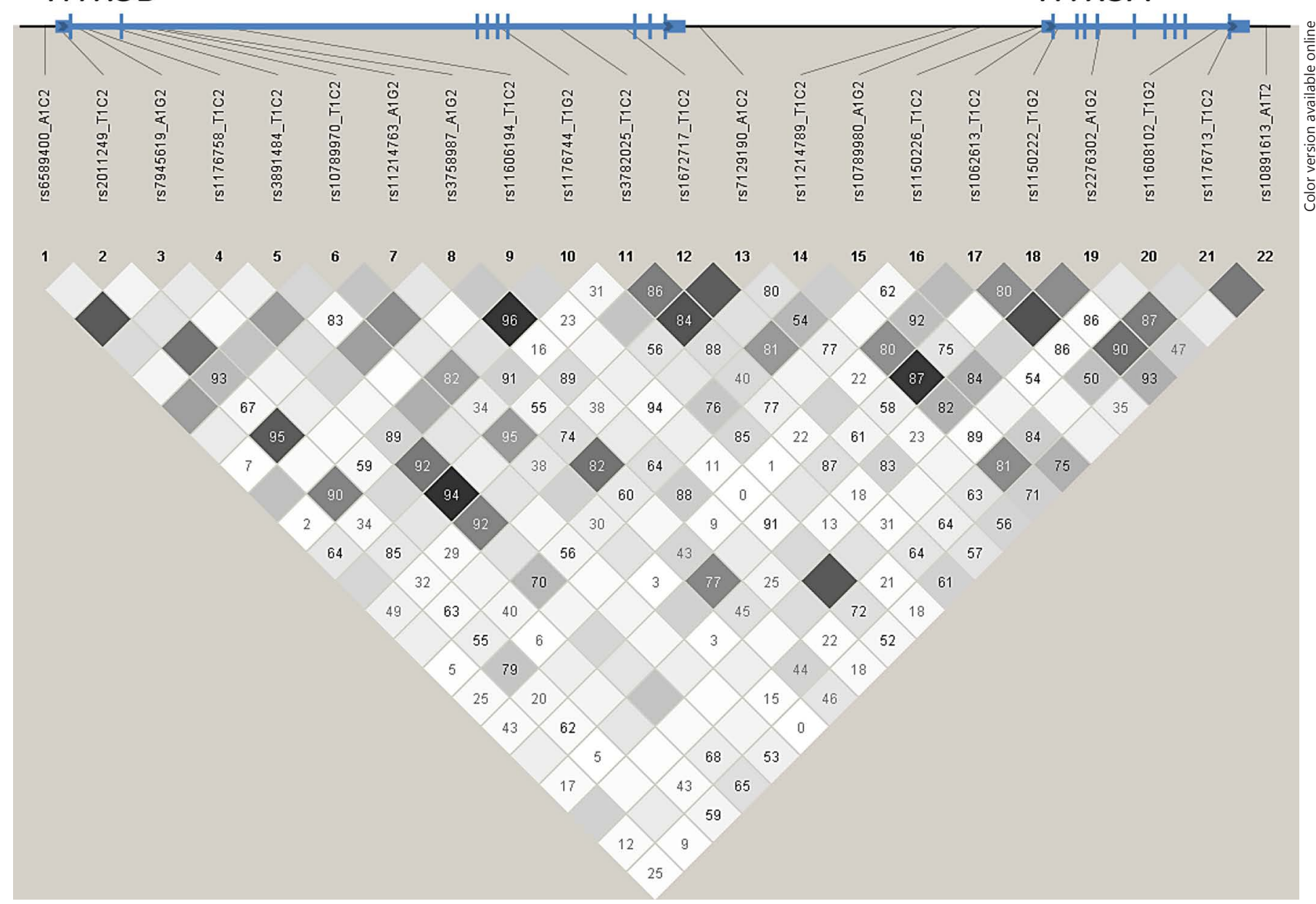

Fig. 1. A schematic diagram of the HTR3B and HTR3A genes, with positions of the tested markers and linkage equilibrium structure based on our genotypes. The values in the figure indicate D-prime values, while the color intensity indicates the strength of correlation between marker pairs.

signed randomly to either clozapine or olanzapine in a 14-week, double-blinded study. Weight change was assessed for up to 14 weeks.

\section{Genotyping}

Venous blood was drawn from the participants, and genomic DNA was extracted from blood lymphocytes using a high salt method, as described previously [23]. Overall, we tested 21 single-nucleotide polymorphisms (SNPs); 8 in HTR3A and 13 in $H T R 3 B$ based on the minimum minor allele frequency of 0.20 using HapMap genotypes (Rel 28 Phase II + III, August10, on NCBI B36 assembly, dbSNP b126; http://hapmap.ncbi.nlm.nih. gov). Specific SNPs were force-included based on previous studies or functional implications [24]. Genotyping of these SNPs were performed on 149 participants using a custom Illumina GoldenGate platform (Illumina, Inc., San Diego, CA, USA) [25]. Genotyping rate was above $97 \%$ for all markers. Genotyping was repeated for $5 \%$ of the sample for quality control purposes, and the repeated genotypes were $100 \%$ concordant. The location of the analyzed markers in these two juxtaposing genes is shown in Figure 1.

\section{Statistical Analyses}

Statistical analyses of demographic variables, which included sex, age at recruitment, and duration of treatment, were performed across samples using Fisher's exact tests, analysis of variance, or Kruskal-Wallis tests (Table 1). The percentage weight change is not significantly different between male and female patients $(p=0.774)$. In terms of genetic analyses, the quantitative variable percent weight change was analyzed using analysis of covariance (ANCOVA), with sex, treatment duration, baseline weight, and clozapine/olanzapine (yes/no) being included as covariates (SPSS version 21, IBM Corp). Analyses were done with all patients with available clinical/weight data $(n=149)$, as well as secondarily with the 86 patients receiving clozapine or olanzapine, the 2 antipsychotics with the highest risk for significant weight gain. Linkage disequilibrium and $r^{2}$ between 
Table 2. Results from analysis of (a) 8 HTR3A and (b) 13 HTR3B SNPs in antipsychotic-associated weight gain in schizophrenia patients of European ancestry

\begin{tabular}{|c|c|c|c|c|c|}
\hline SNP & Genotypes & $\begin{array}{l}\text { Number } \\
\text { of patients }\end{array}$ & $\begin{array}{l}\text { Mean } \\
\text { percentage } \\
\text { weight change }\end{array}$ & $\begin{array}{l}\text { SD of } \\
\text { percentage } \\
\text { weight change }\end{array}$ & $\begin{array}{l}\text { Genotype } p \text { value } \\
\text { (all antipsychotics/ } \\
\text { clozapine or } \\
\text { olanzapine only) }\end{array}$ \\
\hline \multicolumn{6}{|l|}{$\mathbf{a}$} \\
\hline \multirow[t]{3}{*}{ rs10789980_A1G2 } & $\mathrm{A} / \mathrm{A}$ & 29 & 4.83 & 5.77 & $0.099 / 0.651$ \\
\hline & $\mathrm{A} / \mathrm{G}$ & 72 & 3.32 & 5.15 & \\
\hline & $\mathrm{G} / \mathrm{G}$ & 44 & 5.13 & 5.01 & \\
\hline \multirow[t]{3}{*}{ rs1150226_T1C2 } & $\mathrm{T} / \mathrm{T}$ & 1 & 3.56 & & $0.970 / 0.801$ \\
\hline & $\mathrm{T} / \mathrm{C}$ & 24 & 4.17 & 5.57 & \\
\hline & $\mathrm{C} / \mathrm{C}$ & 124 & 4.12 & 5.27 & \\
\hline \multirow[t]{3}{*}{ rs1062613_T1C2 } & $\mathrm{T} / \mathrm{T}$ & 6 & 3.27 & 6.56 & $0.759 / 0.948$ \\
\hline & $\mathrm{T} / \mathrm{C}$ & 54 & 4.01 & 5.24 & \\
\hline & $\mathrm{C} / \mathrm{C}$ & 89 & 4.25 & 5.28 & \\
\hline \multirow[t]{3}{*}{ rs1150222_T1G2 } & $\mathrm{T} / \mathrm{T}$ & 2 & 6.79 & 12.03 & $0.829 / 0.817$ \\
\hline & $\mathrm{T} / \mathrm{G}$ & 43 & 3.87 & 4.79 & \\
\hline & $\mathrm{G} / \mathrm{G}$ & 104 & 4.18 & 5.40 & \\
\hline \multirow[t]{3}{*}{ rs2276302_A1G2 } & $\mathrm{A} / \mathrm{A}$ & 70 & 3.88 & 5.25 & $0.699 / 0.621$ \\
\hline & $\mathrm{A} / \mathrm{G}$ & 69 & 4.38 & 5.31 & \\
\hline & $\mathrm{G} / \mathrm{G}$ & 10 & 4.09 & 5.72 & \\
\hline \multirow[t]{3}{*}{ rs11214789_T1C2 } & $\mathrm{T} / \mathrm{T}$ & 102 & 4.09 & 5.37 & $0.957 / 0.932$ \\
\hline & $\mathrm{T} / \mathrm{C}$ & 43 & 4.19 & 4.96 & \\
\hline & $\mathrm{C} / \mathrm{C}$ & 3 & 4.53 & 9.37 & \\
\hline \multirow[t]{3}{*}{ rs10891613_A1T2 } & $\mathrm{A} / \mathrm{A}$ & 61 & 4.23 & 5.60 & $0.978 / 0.467$ \\
\hline & $\mathrm{A} / \mathrm{T}$ & 74 & 4.05 & 4.91 & \\
\hline & $\mathrm{T} / \mathrm{T}$ & 15 & 3.82 & 5.91 & \\
\hline \multirow[t]{3}{*}{ rs11608102_T1G2 } & $\mathrm{T} / \mathrm{T}$ & 134 & 4.06 & 5.29 & $0.402 / 0.574$ \\
\hline & $\mathrm{T} / \mathrm{G}$ & 15 & 4.71 & 5.35 & \\
\hline & $\mathrm{G} / \mathrm{G}$ & & & & \\
\hline \multicolumn{6}{|l|}{ b } \\
\hline \multirow[t]{3}{*}{ rs3891484_T1C2 } & $\mathrm{T} / \mathrm{T}$ & 112 & 4.18 & 5.36 & $0.125 / 0.317$ \\
\hline & $\mathrm{T} / \mathrm{C}$ & 33 & 4.61 & 4.96 & \\
\hline & $\mathrm{C} / \mathrm{C}$ & 4 & -1.29 & 2.67 & \\
\hline \multirow[t]{3}{*}{ rs10789970_T1C2 } & $\mathrm{T} / \mathrm{T}$ & 31 & 2.84 & 4.64 & $0.296 / 0.748$ \\
\hline & $\mathrm{T} / \mathrm{C}$ & 69 & 4.45 & 5.78 & \\
\hline & $\mathrm{C} / \mathrm{C}$ & 49 & 4.48 & 4.88 & \\
\hline \multirow[t]{3}{*}{ rs11214763_A1G2 } & $\mathrm{A} / \mathrm{A}$ & 5 & 6.09 & 7.99 & $0.255 / 0.600$ \\
\hline & $\mathrm{A} / \mathrm{G}$ & 52 & 4.91 & 4.78 & \\
\hline & $\mathrm{G} / \mathrm{G}$ & 92 & 3.58 & 5.37 & \\
\hline \multirow[t]{3}{*}{ rs3758987_A1G2 } & $\mathrm{A} / \mathrm{A}$ & 80 & 4.17 & 5.54 & $0.062 / 0.071$ \\
\hline & $\mathrm{A} / \mathrm{G}$ & 56 & 4.67 & 5.13 & \\
\hline & $\mathrm{G} / \mathrm{G}$ & 11 & 0.60 & 3.03 & \\
\hline \multirow[t]{3}{*}{ rs1176744_T1G2 } & $\mathrm{T} / \mathrm{T}$ & 74 & 3.80 & 5.34 & $0.099 / \mathbf{0 . 0 4 4}$ \\
\hline & $\mathrm{T} / \mathrm{G}$ & 61 & 5.03 & 5.40 & \\
\hline & $\mathrm{G} / \mathrm{G}$ & 13 & 1.76 & 3.70 & \\
\hline
\end{tabular}


Table 2 (continued)

\begin{tabular}{|c|c|c|c|c|c|}
\hline SNP & Genotypes & $\begin{array}{l}\text { Number } \\
\text { of patients }\end{array}$ & $\begin{array}{l}\text { Mean } \\
\text { percentage } \\
\text { weight change }\end{array}$ & $\begin{array}{l}\text { SD of } \\
\text { percentage } \\
\text { weight change }\end{array}$ & $\begin{array}{l}\text { Genotype } p \text { value } \\
\text { (all antipsychotics/ } \\
\text { clozapine or } \\
\text { olanzapine only) }\end{array}$ \\
\hline \multirow[t]{3}{*}{ rs3782025_T1C2 } & $\mathrm{T} / \mathrm{T}$ & 46 & 4.11 & 5.64 & \multirow[t]{3}{*}{$0.962 / 0.834$} \\
\hline & $\mathrm{T} / \mathrm{C}$ & 78 & 4.19 & 5.29 & \\
\hline & $\mathrm{C} / \mathrm{C}$ & 25 & 3.97 & 4.74 & \\
\hline \multirow[t]{3}{*}{ rs1672717_T1C2 } & $\mathrm{T} / \mathrm{T}$ & 62 & 3.54 & 4.82 & \multirow[t]{3}{*}{$0.431 / 0.410^{\mathrm{b}}$} \\
\hline & $\mathrm{T} / \mathrm{C}$ & 66 & 4.70 & 6.00 & \\
\hline & $\mathrm{C} / \mathrm{C}$ & 21 & 4.03 & 3.99 & \\
\hline \multirow[t]{3}{*}{ rs2011249_T1C2 } & $\mathrm{T} / \mathrm{T}$ & 8 & -0.40 & 2.20 & \multirow[t]{3}{*}{$\mathbf{0 . 0 4 7 / 0 . 2 0 6}$} \\
\hline & $\mathrm{T} / \mathrm{C}$ & 45 & 4.56 & 4.94 & \\
\hline & $\mathrm{C} / \mathrm{C}$ & 96 & 4.30 & 5.47 & \\
\hline \multirow[t]{3}{*}{ rs6589400_A1C2 } & $\mathrm{A} / \mathrm{A}$ & 93 & 4.37 & 4.81 & \multirow[t]{3}{*}{$0.477^{c} / 0.663$} \\
\hline & $\mathrm{A} / \mathrm{C}$ & 45 & 3.44 & 6.36 & \\
\hline & $\mathrm{C} / \mathrm{C}$ & 8 & 4.52 & 4.85 & \\
\hline \multirow[t]{3}{*}{ rs11606194_T1C2 } & $\mathrm{T} / \mathrm{T}$ & 130 & 3.98 & 5.25 & \multirow[t]{3}{*}{$0.444 / 0.289$} \\
\hline & $\mathrm{T} / \mathrm{C}$ & 18 & 4.98 & 5.65 & \\
\hline & $\mathrm{C} / \mathrm{C}$ & 1 & 7.42 & & \\
\hline \multirow[t]{3}{*}{ rs1176758_T1C2 } & $\mathrm{T} / \mathrm{T}$ & 62 & 3.80 & 5.00 & \multirow[t]{3}{*}{$0.614^{\mathrm{c}} / 0.439$} \\
\hline & $\mathrm{T} / \mathrm{C}$ & 72 & 4.57 & 5.80 & \\
\hline & $\mathrm{C} / \mathrm{C}$ & 15 & 3.33 & 3.61 & \\
\hline \multirow[t]{3}{*}{ rs7129190_A1C2 } & $\mathrm{A} / \mathrm{A}$ & 45 & 3.96 & 5.17 & \multirow[t]{3}{*}{$0.727 / 0.426$} \\
\hline & $\mathrm{A} / \mathrm{C}$ & 74 & 4.36 & 5.50 & \\
\hline & $\mathrm{C} / \mathrm{C}$ & 30 & 3.81 & 5.03 & \\
\hline \multirow[t]{3}{*}{ rs7945619_A1G2 } & $\mathrm{A} / \mathrm{A}$ & 4 & 2.82 & 5.58 & \multirow[t]{3}{*}{$0.313^{c} / 0.607^{c}$} \\
\hline & $\mathrm{A} / \mathrm{G}$ & 35 & 3.25 & 6.31 & \\
\hline & $\mathrm{G} / \mathrm{G}$ & 109 & 4.46 & 4.94 & \\
\hline
\end{tabular}

${ }^{a} p$ values from ANCOVA (comparison among three genotype groups) of percent weight change with sex, treatment duration, baseline weight, and clozapine/olanzapine (yes/no) as covariates. ${ }^{\text {b }}$ Significant Levene's test. ${ }^{c}$ Significant Lack of Fit test. $p$ values in bold font $<0.05$.

marker pairs, as determined by Haploview 4.1 [26], is shown in Figure 1 . We also performed haplotype analysis with covariates using UNPHASED version 3.1.5 [27]. Furthermore, we used the program mbmdr to detect gene-gene interaction between HTR $3 A$ and $H T R 3 B$, with significance estimated by permutation testing [28]. Based on genotypic correlation among the tested SNPs, the effective number of independent (uncorrelated) markers was determined to be 13.48; thus, we adjusted the significance threshold for multiple testing in the present study to 0.0038 [29].

\section{Results}

Table 2 presents the results from analyses of the percent weight change in antipsychotic-treated SCZ patients of European ancestry. There were no significant devia- tions of genotype distributions from Hardy-Weinberg equilibrium $(p>0.05)$.

The HTR3B rs2011249 marker was nominally associated with percent weight gain from the ANCOVA $(p<$ $0.05)$ in the overall sample. More specifically, the TT genotype (mean weight change $-0.40 \pm 2.20 \%$ ) was associated with lower weight gain than $\mathrm{C}$ allele-carrying genotypes $(4.36 \pm 5.28 \%)$ (ANCOVA, $p=0.014)$. The HTR3B rs1176744 marker was nominally associated with percent weight gain from the ANCOVA $(p<0.05)$ in the subgroup of patients treated with clozapine or olanzapine. More specifically, the TG genotype (mean weight change $6.21 \pm$ $5.31 \%$ ) was associated with higher percent weight change than the GG carrying genotype $(1.33 \pm 3.54 \%)$ (ANCO$\mathrm{VA}, p=0.036)$. These findings did not survive correction 
for multiple testing. Results from the haplotypic analyses were not significant $(p>0.05)$. Results from the pairwise interaction analyses between HTR3A SNPs and HTR3B SNPs did not yield significant findings after multiple-testing correction. The top findings from the interaction analysis was observed between rs10789980 and rs6589400 $(p=0.031)$, where double heterozygotes were associated with significantly lower weight gain $(1.10 \pm 5.34 \%)$ than the other genotype combinations $(4.76 \pm 5.08 \%)$.

\section{Discussion}

This study is the first to focus on the HTR $3 A$ and $H T R 3 B$ genes in AIWG in SCZ patients of European ancestry. Previously, the serotonin $2 \mathrm{C}$ receptor gene has been implicated in AIWG [8]. Given the preclinical evidence of the 5 -HT3 receptors in weight regulation, we investigated common polymorphisms across the HTR $3 A$ and HTR $3 B$ genes. We observed nominal associations of HTR $3 B$ SNPs rs1176744 and rs2011249 with AIWG, as well as a possible interaction between the HTR3A rs 10789980 and HTR3B rs6589400 SNPs. These findings did not survive correction for multiple testing, thus our findings did not support a major role for these receptors in AIWG.

The present study could have been influenced by a number of limitations in addition to the limited sample size. These include heterogeneity within our sample in terms of clinical and medication history, as well as confounding by co-medication and substance use. Future studies investigating both common and rare variants across these genes in larger samples are needed before the role of these genes in AIWG can be dismissed conclusively [30].

Additional, 5-HT3 receptor subunits (5-HT3C, 5-HT3D, and 5-HT3E) have been described recently. The genes coding for these subunits may be of interest for future AIWG studies when more evidence on their role in the regulation of 5-HT3 receptor signaling [31] and their interaction with antipsychotics become available. A number of candidate genes have been identified by our group and others (e.g. [18, 32-35]) and replicated for AIWG. Given the reported synergistic effect of 5-HT3 and cholecystokinin on the regulation of food intake [7] and the reported association of the cholecystokinin $\mathrm{B}$ receptor gene with AIWG, additional gene-gene interaction (e.g. [36]) and pathway analyses (e.g. [37]) using larger samples may lead to more fruitful research findings that can be translated to better antipsychotic treatment outcome for patients.

\section{Acknowledgements}

We are grateful to the patients who agreed to participate in our studies.

\section{Disclosure Statement}

J.L.K. honoraria from Roche, Novartis, and Lilly. H.Y.M. has received grants, or payment for lectures, or is or was a consultant to: Sunovion Novartis, TEVA, Bioline Rx, BI, Envivo, Companion Dx, Janssen Pharma, Lundbeck. H.Y.M. employment includes Suregene and Northwestern University, and he is an expert testimony for Janssen. J.L.K., D.J.M., C.C.Z., E.J.B., A.K.T., and N.C.: patent application: "Compositions and Methods for the Treatment and Prevention of Antipsychotic Medication-Induced Weight Gain." J.L.K., D.J.M., and C.C.Z.: patent application: "Genetic Markers for Antipsychotic Induced Weight Gain and Methods for Use Thereof." H.Y.M. is a shareholder of ACADIA, GlaxoSmithKline, and Suregene. H.Y.M. is a speaker or board member of Sunovion, TEVA, Bioline Rx, Janssen, BI, and is an advisor to Centerstone Research Institute. H.Y.M. honoraria from Lundbeck, BI, Sunovion, TEVA, Bioline Rx, and Janssen Pharma. J.A.L. serves on the Advisory Board of Intracellular Therapies. He does not receive direct financial compensation or salary support for participation in research, consulting, or advisory board activities. He receives grant support from Allon, Biomarin, Eli Lilly, F. Hoffmann-La Roche/Genentech, GlaxoSmithKline, Merck, Novartis, Pfizer, Psychogenics, Sepracor (Sunovion), and Targacept; and he holds a patent from Repligen. N.F. and S.A.S. have nothing to disclose. D.J.M. has received funds from the Canadian Institutes of Health Research (MOP 142192), National Institutes of Health, the Centre for Addiction and Mental Health Foundation (Joanne Murphy Professorship), the Canadian Biomarker Integration Network in Depression, and the Ontario Brain Institute.

References

Neuropsychobiology 2016;74:169-175 DOI: $10.1159 / 000457903$
1 Arranz MJ, de Leon J: Pharmacogenetics and pharmacogenomics of schizophrenia: a review of last decade of research. Mol Psychiatry 2007;12:707-747.

2 Müller DJ, Kennedy JL: Genetics of antipsychotic treatment emergent weight gain in schizophrenia. Pharmacogenomics 2006; 7 : 863-887.

3 Strange PG: Antipsychotic drugs: importance of dopamine receptors for mechanisms of therapeutic actions and side effects. Pharmacol Rev 2001;53:119-133.

4 Vojvoda D, Grimmell K, Sernyak M, Mazure CM: Monozygotic twins concordant for response to clozapine. Lancet 1996;347:61.

5 Gebhardt S, Theisen FM, Haberhausen M, Heinzel-Gutenbrunner M, Wehmeier PM, Krieg JC, Kühnau W, Schmidtke J, Remschmidt $\mathrm{H}$, Hebebrand J: Body weight gain induced by atypical antipsychotics: an extension of the monozygotic twin and sib pair study. J Clin Pharm Ther 2010;35:207-211. 
6 Lett TA, Wallace TJ, Chowdhury NI, Tiwari AK, Kennedy JL, Muller DJ: Pharmacogenetics of antipsychotic-induced weight gain: review and clinical implications. Mol Psychiatry 2012;17:242-266.

7 Hayes MR, Covasa M: CCK and 5-HT act synergistically to suppress food intake through simultaneous activation of CCK-1 and 5-HT3 receptors. Peptides 2005;26:2322-2330.

8 Sicard MN, Zai CC, Tiwari AK, Souza RP, Meltzer HY, Lieberman JA, Kennedy JL, Muller DJ: Polymorphisms of the HTR2C gene and antipsychotic-induced weight gain: an update and meta-analysis. Pharmacogenomics 2010;11:1561-1571.

9 Feinle C, Read NW: Ondansetron reduces nausea induced by gastroduodenal stimulation without changing gastric motility. Am J Physiol 1996;271(4 pt 1):G591-G597.

10 Ginawi OT, Al-Majed AA, Al-Suwailem AK: Ondansetron, a selective 5-HT3 antagonist, antagonizes methamphetamine-induced anorexia in mice. Pharmacol Res 2005;51:255259.

11 Weber S, Volynets V, Kanuri G, Bergheim I, Bischoff SC: Treatment with the 5-HT3 antagonist tropisetron modulates glucose-induced obesity in mice. Int J Obes (Lond) 2009; 33:1339-1347.

12 Ohara-Imaizumi M, Kim H, Yoshida M, Fujiwara T, Aoyagi K, Toyofuku Y, Nakamichi Y, Nishiwaki C, Okamura T, Uchida T, Fujitani Y, Akagawa K, Kakei M, Watada H, German MS, Nagamatsu S: Serotonin regulates glucose-stimulated insulin secretion from pancreatic $\beta$ cells during pregnancy. Proc Natl Acad Sci USA 2013;110:19420-19425.

13 Oh CM, Namkung J, Go Y, Shong KE, Kim K, Kim H, Park BY, Lee HW, Jeon YH, Song J, Shong M, Yadav VK, Karsenty G, Kajimura S, Lee IK, Park S, Kim H: Regulation of systemic energy homeostasis by serotonin in adipose tissues. Nat Commun 2015;6:6794.

14 Lummis SC: 5-HT(3) receptors. J Biol Chem 2012;287:40239-40245.

15 Rammes G, Eisensamer B, Ferrari U, Shapa M, Gimpl G, Gilling K, Parsons C, Riering K, Hapfelmeier G, Bondy B, Zieglgänsberger W, Holsboer F, Rupprecht R: Antipsychotic drugs antagonize human serotonin type 3 receptor currents in a noncompetitive manner. Mol Psychiatry 2004;9:846-858, 818.

16 First MB, Gibbon M, Spitzer RL, Williams JB Structured Clinical Interview for DSM-IV Axis I Disorders-Research Version (SCID$\mathrm{I} / \mathrm{P}$, version 2.0, February, Final Version) Washington, American Psychiatric Press, 1996.

17 Endicott J: Good diagnoses require good diagnosticians: collecting and integrating the data. Am J Med Genet 2001;105:48-49.
18 Muller DJ, Zai CC, Sicard M, Remington E, Souza RP, Tiwari AK, Hwang R, Likhodi O, Shaikh S, Freeman N, Arenovich T, Heinz A, Meltzer HY, Lieberman JA, Kennedy JL: Systematic analysis of dopamine receptor genes (DRD1-DRD5) in antipsychotic-induced weight gain. Pharmacogenomics J 2012;12: 156-164.

19 Masellis M, Basile V, Meltzer HY, Lieberman JA, Sevy S, Macciardi FM, Cola P, Howard A, Badri F, Nöthen MM, Kalow W, Kennedy JL: Serotonin subtype 2 receptor genes and clinical response to clozapine in schizophrenia patients. Neuropsychopharmacology 1998;19: 123-132.

20 Kane JM, Honigfeld G, Singer J, Meltzer H: Clozapine in treatment-resistant schizophrenics. Psychopharmacol Bull 1988;24:6267.

21 Volavka J, Czobor P, Sheitman B, Lindenmayer JP, Citrome L, McEvoy JP, Cooper TB, Chakos M, Lieberman JA: Clozapine, olanzapine, risperidone, and haloperidol in the treatment of patients with chronic schizophrenia and schizoaffective disorder. Am J Psychiatry 2002;159:255-262.

22 Kay SR, Fiszbein A, Opler LA: The positive and negative syndrome scale (PANSS) for schizophrenia. Schizophr Bull 1987;13:261276.

23 Lahiri DK, Nurnberger JI Jr: A rapid non-enzymatic method for the preparation of HMW DNA from blood for RFLP studies. Nucleic Acids Res 1991;19:5444.

$24 \mathrm{Xu} \mathrm{Z}$, Taylor JA: SNPinfo: integrating GWAS and candidate gene information into functional SNP selection for genetic association studies. Nucleic Acids Res 2009;37:W600W605.

25 Hodgkinson CA, Yuan $\mathrm{Q}, \mathrm{Xu} \mathrm{K}$, Shen $\mathrm{PH}$ Heinz E, Lobos EA, Binder EB, Cubells J, Ehlers CL, Gelernter J, Mann J, Riley B, Roy A, Tabakoff B, Todd RD, Zhou Z, Goldman D: Addictions biology: haplotype-based analysis for 130 candidate genes on a single array. Alcohol Alcohol 2008;43:505-515.

26 Barrett JC, Fry B, Maller J, Daly MJ: Haploview: analysis and visualization of $\mathrm{LD}$ and haplotype maps. Bioinformatics 2005;21: 263-265.

27 Dudbridge F: Likelihood-based association analysis for nuclear families and unrelated subjects with missing genotype data. Hum Hered 2008;66:87-98.

28 Calle ML, Urrea V, Malats N, Van Steen K: mbmdr: an $\mathrm{R}$ package for exploring genegene interactions associated with binary or quantitative traits. Bioinformatics 2010;26: 2198-2199.

29 Li J, Ji L: Adjusting multiple testing in multilocus analyses using the eigenvalues of a correlation matrix. Heredity (Edinb) 2005;95: 221-227.
30 Matosin N, Frank E, Engel M, Lum JS, Newell KA: Negativity towards negative results: a discussion of the disconnect between scientific worth and scientific culture. Dis Model Mech 2014;7:171-173.

31 Holbrook JD, Gill CH, Zebda N, Spencer JP, Leyland R, Rance KH, Trinh H, Balmer G, Kelly FM, Yusaf SP, Courtenay N, Luck J, Rhodes A, Modha S, Moore SE, Sanger GJ, Gunthorpe MJ: Characterisation of 5-HT3C, 5-HT3D and 5-HT3E receptor subunits: evolution, distribution and function. J Neurochem 2009;108:384-396.

32 Chowdhury NI, Tiwari AK, Souza RP, Zai CC, Shaikh SA, Chen S, Liu F, Lieberman JA, Meltzer HY, Malhotra AK, Kennedy JL, Muller DJ: Genetic association study between antipsychotic-induced weight gain and the melanocortin-4 receptor gene. Pharmacogenomics J 2013;13:272-279.

33 Malhotra AK, Correll CU, Chowdhury NI, Muller DJ, Gregersen PK, Lee AT, Tiwari AK, Kane JM, Fleischhacker WW, Kahn RS, Ophoff RA, Meltzer HY, Lencz T, Kennedy JL: Association between common variants near the melanocortin 4 receptor gene and severe antipsychotic drug-induced weight gain. Arch Gen Psychiatry 2012;69:904-912.

34 Nurmi EL, Spilman SL, Whelan F, Scahill LL, Aman MG, McDougle CJ Arnold LE, Handen B, Johnson C, Sukhodolsky DG, Posey DJ, Lecavalier L, Stigler KA, Ritz L, Tierney E, Vitiello B, McCracken JT; Research Units on Pediatric Psychopharmacology Autism Network: Moderation of antipsychotic-induced weight gain by energy balance gene variants in the RUPP autism network risperidone studies. Transl Psychiatry 2013;3:e274.

35 Tiwari AK, Zai CC, Likhodi O, Lisker A, Singh D, Souza RP, Batra P, Zaidi SH, Chen S, Liu F, Puls I, Meltzer HY, Lieberman JA, Kennedy JL, Müller DJ: A common polymorphism in the cannabinoid receptor 1 (CNR1) gene is associated with antipsychotic-induced weight gain in Schizophrenia. Neuropsychopharmacology 2010;35:1315-1324.

36 Zai CC, Tiwari AK, De Luca V, Muller DJ, Bulgin N, Hwang R, Zai GC, King N, Voineskos AN, Meltzer HY, Lieberman JA, Potkin SG, Remington G, Kennedy JL: Genetic study of BDNF, DRD3, and their interaction in tardive dyskinesia. Eur Neuropsychopharmacol 2009;19:317-328.

37 Creta E, Fabbri C, Serretti A: Genetics of second-generation antipsychotic and mood stabilizer-induced weight gain in bipolar disorder: common and specific effects of key regulators of fat-mass homoeostasis genes. Pharmacogenet Genomics 2015;25:354-362. 